Gut, 1972, 13, 471-476

\title{
Hormone-elicited enzyme release by the small intestinal wall
}

\author{
H. GÖTZE, J. W. ADELSON, H. B. HAdORN, R. PORTMANN, AND \\ V. TROESCH
}

From the Gastrointestinal Research Unit, Department of Paediatrics, University of Berne, Switzerland

SUMMARY Three enzymes of intestinal origin-enterokinase, alkaline phosphatase, and sucrasewere released into the perfused small intestinal lumen of the rat upon intravenous injection of the gastrointestinal hormone cholecystokinin-pancreozymin (CCK-PZ).

The presence of bile in the perfusion fluid greatly augmented this release. The results suggest that a combined mechanism of enzyme liberation due to direct hormonal stimulation of the gut wall and further solubilization of released intestinal enzymes by bile may be responsible for the appearance of these enzymes in the gut lumen.

Several enzymes of intestinal origin have important roles in the digestion of proteins and carbohydrates. Sucrase (Miller and Crane, 1961) and enterokinase (Nordström and Dahlqvist, 1970) are associated with mucosal cells and are localized on the brush border membrane of the intestinal epithelial cell. The specific localization of sucrase at the mucosalluminal interface is thought to be of functional importance in the coupling of digestion to transport (Crane, 1968). Little or no sucrase activity has been found in the intestinal lumen (Semenza, 1968). Enterokinase, by contrast, is found in a particulate form on the brush border membrane and additionally in a soluble form in the intestinal lumen where it exerts its function in initiating the process of zymogen activation (Hadorn, Steiner, Sumida, and Peters, 1971). The presence of intestinal enzymes in the gut lumen has usually been attributed to loss of enzyme from the mucosa due to extensive desquamation of cells which is known to occur in the gut.

\section{Methods}

We employed a simple intestinal perfusion system. Male rats, weighing 300-400 g, Wistar strain, starved overnight but allowed water, were anaesthetized with sodium pentobarbital. A laparotomy was performed, and the pyloric region of the stomach incised for $5 \mathrm{~mm}$ just proximal to the pyloric sphincter and again $35-40 \mathrm{~cm}$ distal to this point. An inlet tube was passed through the pyloric

Received for publication 11 April 1972. sphincter about $1 \mathrm{~cm}$ into the duodenum and ligated in place. An outlet tube was fixed at the distal incision which was allowed to drip into small plastic vessels. The samples were placed on ice immediately after collection. A roller pump operating at a fixed rate (indicated in the figure legends) led to the inlet tube from a reservoir containing perfusion fluid. The perfusion fluid employed was physiological saline which was replaced in certain experiments by previously collected rat bile, diluted $1: 1$ with saline. In some experiments the common pancreatic-bile duct was tightly ligated as close as possible to the point where the duct entered the duodenal wall. All animals in which an accessory pancreatic duct was found were rejected in this study. Injections were made in saline solution through the cannulated femoral vein. Four assays were done according to established procedures: bulk protein (Lowry, Rosebrough, Farr, and Randall, 1951); sucrase (Messer and Dahlqvist, 1966); enterokinase (Hadorn Tarlow, Lloyd, and Wolf, 1969). This latter method was modified by the use of $100 \mu \mathrm{l} 0.05 \mathrm{M}$ citrate buffer, $p \mathrm{H} \mathrm{5.6}$, and $100 \mu \mathrm{l}$ of crystalline bovine trypsinogen (FLUKA, $2 \mathrm{mg}$ per $\mathrm{ml}$ of $0.005 \mathrm{M} \mathrm{HCl}$ ) in a total volume of $0.75 \mathrm{ml}$. Alkaline phosphatase was measured according to the Worthington Biochemical Co. modification of Hofstee's method (1954). The enzyme activities are expressed in International Units ( $\mu$ Moles substrate split per minute) per ml. Enterokinase activity is expressed as micrograms trypsin formed per minute per millilitre. Secretin and cholecystokinin-pancreozymin were purchased from the Gastrointestinal Hormone 
Research Department, Karolinska Institutet, Stockholm.

\section{Results}

Initial perfusion of the intestine with physiological saline resulted in initial high enzyme levels in the perfusion fluid due to a 'washing out' period. After 30 minutes to one hour the levels diminished to a stable low basal value. The effect of intravenous injection of 1 Unit of secretin and 1 Unit of CCK-PZ upon the concentration of enterokinase, sucrase, and alkaline phosphatase in the effluent of the perfusion is shown in Table $I$, and an experiment

\begin{tabular}{|c|c|c|c|c|c|}
\hline Common Duct & Time Related to Injection & \multicolumn{2}{|c|}{ Enterokinase (IU) } & Sucrase $\left(I U \times 10^{-3}\right)$ & Alkaline Phosphatase (IU) \\
\hline Open $(n=3)$ & $\begin{array}{l}\text { Before } \\
\text { After }\end{array}$ & \multicolumn{2}{|r|}{$\begin{array}{l}14.3 \quad(2.31) \\
71.3 \quad(18.38) \\
P<0.025\end{array}$} & $\begin{array}{r}4 \cdot 13(1.15) \\
27.85(3.63) \\
P<0.0025\end{array}$ & $\begin{array}{ll}0.17 & (0.04) \\
1.53 & (0.43) \\
P<0.05\end{array}$ \\
\hline Closed $(n=10)$ & $\begin{array}{l}\text { Before } \\
\text { After }\end{array}$ & \multicolumn{2}{|r|}{$\begin{array}{l}1.99(0.426) \\
8.95(1.90) \\
P<0.0025\end{array}$} & $\begin{array}{l}2.55(0.566) \\
11.31(2.97) \\
P<0.01\end{array}$ & $\begin{array}{l}0.089(0.012) \\
0.622(0.082) \\
P<0.0005\end{array}$ \\
\hline \multirow[t]{3}{*}{ Closed $(n=3)$} & Before (saline perfusion) & (A) & $2.44 \quad(0.427)$ & $2.98(1.04)$ & $0.12(0.002)$ \\
\hline & Before (bile perfusion) & \multicolumn{2}{|c|}{ (B) $\mathrm{P}_{1}<0.0025$} & $\begin{array}{l}9.94(2.36) \\
P_{1}<0.025\end{array}$ & $\begin{array}{l}0.19(0.003) \\
P_{1}<0.05\end{array}$ \\
\hline & After (bile perfusion) & (C) & $P_{2}<0.05$ & $\begin{array}{l}31.23(1.069) \\
P_{2}<0.0125\end{array}$ & $\begin{array}{l}0.6 \quad(0.015) \\
\mathrm{P}_{2}<0.05\end{array}$ \\
\hline
\end{tabular}

Table I Total enzyme output per $7 \cdot 5$ min in perfused rat small instestine ${ }^{1}$

${ }^{1}$ In each experiment the enzyme output was determined for four $7.5 \mathrm{~min}$ periods immediately before and following intravenous injection of 1 Unit of CCK-PZ. Perfusion was with saline except where indicated. Figures in the table are the average total enzyme output per period. The standard error of the mean is given in parentheses. $P$ values were calculated from the $t$ test for paired observations.

$P_{1}$ is $P$ value for difference between period $B$ and period $A$.

$P_{2}$ is $\mathbf{P}$ value for difference between period $C$ and period $B$.
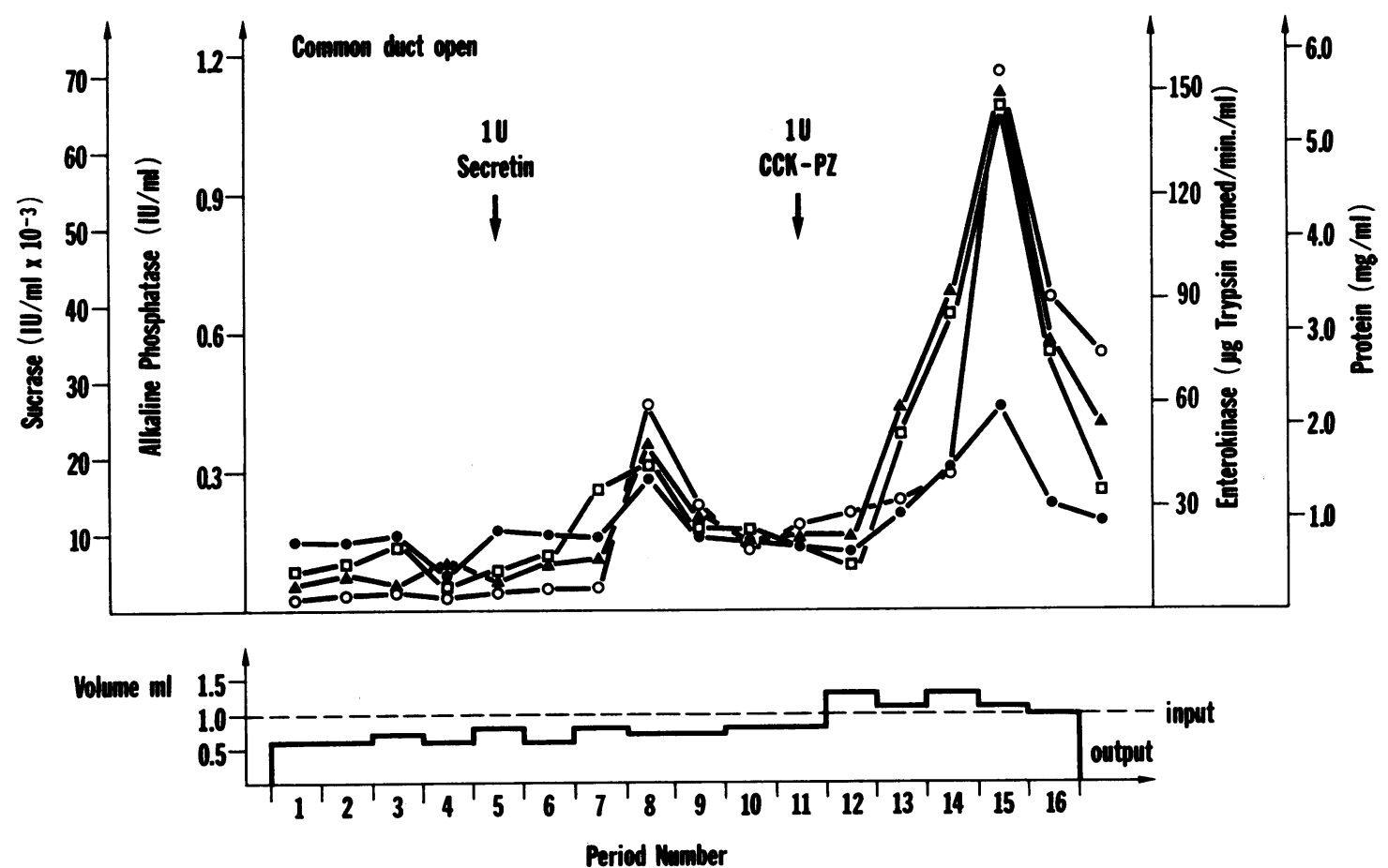

Fig. 1 Effect of secretin and CCK-PZ injection upon release of intestinal hydrolases and protein into the perfused small intestine of the rat with open common bile and pancreatic duct. $(\boldsymbol{\Delta}-\mathbf{\Lambda})$ sucrase; $(\square-\square)$ enterokinase; $(\bigcirc-\bigcirc)$ alkaline phosphatase; $(\bullet-))$ protein. Collection periods were 7.5 min; perfusion was done with saline; input rate was $0.13 \mathrm{ml}$ per minute. 
from a single animal in Figure 1. A striking fivefold rise in the output of enterokinase, and seven- and ninefold increases in sucrase and alkaline phosphatase respectively were observed after CCK-PZ injection. The injection of 1 Unit of secretin elicited a smaller increase in the concentrations of the three enzymes.

In otherwise identical experiments the common pancreatic and bile duct of rats was ligated (Fig. 2). Under these conditions injection of CCK-PZ but not secretin led to clear increases in all three enzymes (Table I). The increase observed in sucrase output, however, was variable. The outputs of enterokinase, sucrase, and alkaline phosphatase were reduced under these conditions to about 12,40 , and $35 \%$ respectively of those levels observed when the ducts were patent (cf. Fig. 1, Table I).

To assess further the interaction of bile with the CCK-PZ-elicited liberation of intestinal enzymes, perfusions with bile-containing fluid were made in rats in which the common pancreatic and bile duct was ligated (Table I, Fig. 3). The perfusion was begun with physiological saline and then continued with rat bile diluted $1: 2$ with saline.
After saline perfusion, perfusion with bile resulted in a considerable increase in the level of each substance tested, including sucrase and gross protein. The presence of bile partially restored the CCK-PZelicited increase in enzyme levels to nearly the same range observed when the common pancreatic-bile duct was open (cf. Fig. 1).

Control enzyme determinations were run in which bile was added to saline-containing perfusates to ascertain whether the presence of bile would alter the observed enzyme levels. In the case of sucrase and alkaline phosphatase, no changes were caused by adding bile. In the case of enterokinase, adding bile resulted in activation of this enzyme, as previously reported by Hadorn et al (1971).

Changes in the volume of effluent fluid were observed with respect to the input volume. Perfusion in general resulted in approximately $30-50 \%$ loss of fluid at the rate employed (Figs. 1, 2, and 3). The administration of CCK-PZ caused an increase in the volume of perfusate of approximately 30 to $40 \%$ with respect to the preinjection output volume.

The rat bile employed in the perfusion contained no measurable sucrase or enterokinase activity. A
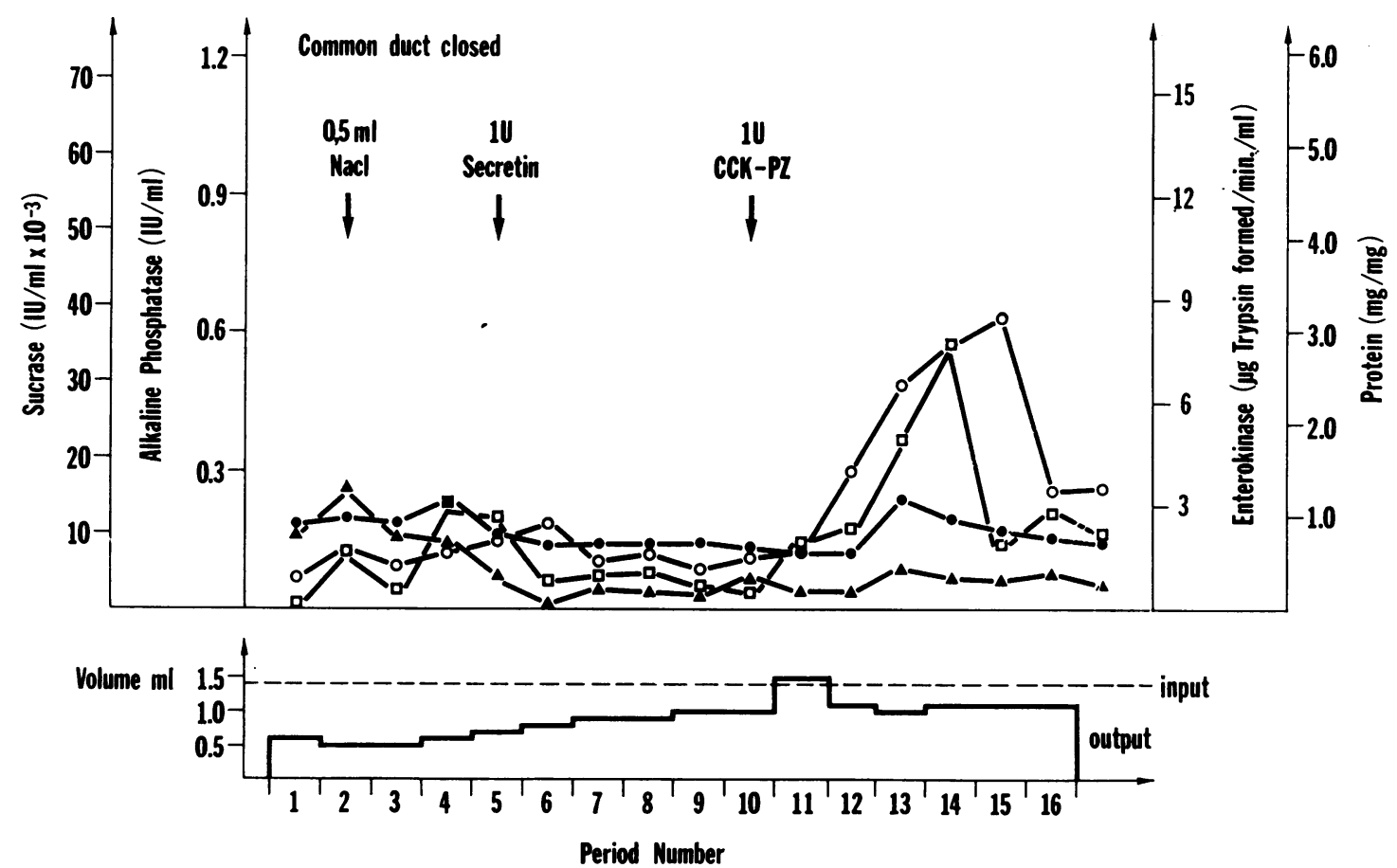

Fig. 2 Effect of secretin and CCK-PZ injection upon intestinal enzyme release. Common bile and pancreatic duct closed. Curves labelled as in Figure 1. Collection periods were 7.5 min; perfusion was done with saline; input rate was $0 \cdot 19 \mathrm{ml}$ per minute. 

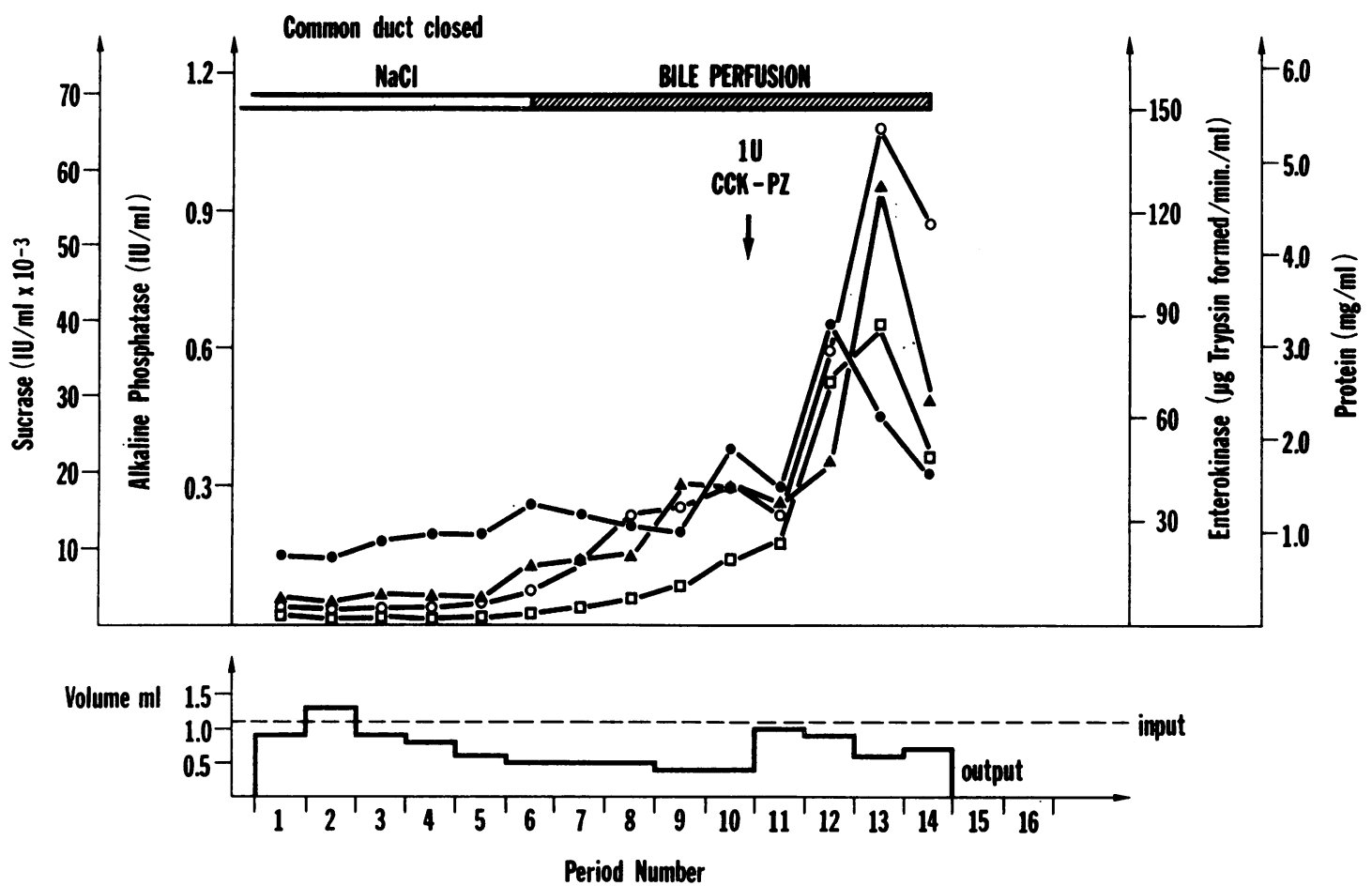

Fig. 3 Effect of CCK-PZ injection upon intestinal enzyme release. Common bile and pancreatic duct closed. Curves labelled as in Figure 1. Collection periods were five min; perfusion was done with saline, then with rat bile diluted 1:2 with saline as indicated; input rate was $0.22 \mathrm{ml}$ per minute.

\begin{tabular}{|c|c|c|c|c|c|c|c|c|c|}
\hline \multirow{4}{*}{$\begin{array}{l}\text { CCK-PZ } \\
\text { (Units/kg body weight) }\end{array}$} & \multicolumn{9}{|c|}{ Alkaline Phosphatase Concentration (International Units/ml of perfusate) } \\
\hline & \multicolumn{4}{|c|}{ Before Injection } & \multicolumn{5}{|c|}{ After Injection } \\
\hline & \multicolumn{3}{|l|}{ Period } & \multirow{2}{*}{$\begin{array}{l}\text { Mean of } \\
\text { Periods }\end{array}$} & \multicolumn{3}{|l|}{ Period } & \multirow{2}{*}{$\begin{array}{l}\text { Mean of } \\
\text { Periods }\end{array}$} & \multirow{2}{*}{$\begin{array}{l}\text { Difference } \\
\text { of Means }\end{array}$} \\
\hline & 1 & 2 & 3 & & 1 & 2 & 3 & & \\
\hline $\begin{array}{l}0.1 \\
0 \cdot 2 \\
1\end{array}$ & $\begin{array}{l}0.0684 \\
0.0591 \\
0.1368\end{array}$ & $\begin{array}{l}0.0421 \\
0.1846 \\
0.0889\end{array}$ & $\begin{array}{l}0.0615 \\
0.1926 \\
0.1003\end{array}$ & $\begin{array}{l}0.0573 \\
0 \cdot 1588 \\
0 \cdot 1087\end{array}$ & $\begin{array}{l}0.0832 \\
0.3214 \\
0.2599\end{array}$ & $\begin{array}{l}0.0729 \\
0.2291 \\
0.7524\end{array}$ & $\begin{array}{l}0.0752 \\
0.2268 \\
0.5198\end{array}$ & $\begin{array}{l}0 \cdot 0771 \\
0 \cdot 2591 \\
0.5107\end{array}$ & $\begin{array}{l}0 \cdot 0198 \\
0 \cdot 1003 \\
0 \cdot 4020\end{array}$ \\
\hline
\end{tabular}

Table II Effect of increasing doses of CCK-PZ on alkaline phosphatase concentrations in the perfusate ${ }^{1}$

${ }^{1}$ The concentration of alkaline phosphatase was determined for three 7.5 minute periods immediately before and three periods immediately following intravenous injection of the indicated dose of CCK-PZ. The differences in the alkaline phosphatase concentrations were obtained by subtraction of the average preinjection concentration from the average postinjection concentration. The common pancreatic-bile duct was ligated as described in methods.

correction was made for endogenous biliary protein. We also observed none of the expected alkaline phosphatase activity in the pre-collected rat bile; this was possibly lost during storage before perfusion.

In several experiments the perfusion was done with a mixture of pure bile salts at a physiological concentration for the rat as described by Paumgartner, Horak, Probst, and Grabner (1971); the effect was essentially identical to the effect observed during perfusion of native rat bile.
The effect of CCK-PZ upon alkaline phosphatase levels in the absence of bile and pancreatic fluid was dose-dependent and is shown in Table II. Increasing doses of CCK-PZ from 0.1 to 1 Unit per kilogram body weight led to increasing liberation of this enzyme.

The enzymes released in the absence of bile differed in their sedimentability. Sucrase and alkaline phosphatase were $85 \%$ sedimented by centrifugation at $113000 \times g$ at $0^{\circ} \mathrm{C}$ for one hour. 
In contrast enterokinase activity remained virtually entirely in the supernatant. In the presence of bile only $25 \%$ of the sucrase and less than $5 \%$ of the alkaline phosphatase activity remained capable of sedimenting.

\section{Discussion}

The results indicate that cholecystokinin-pancreozymin elicits the release of enzymes from the intestinal wall. The dose range in which the enzyme release occurs appears to be well within the range reported to elicit pancreatic enzyme secretion in dogs and man on a per $\mathrm{kg}$ body weight basis (Hanscom and Littman, 1963; Preshaw, Adashek, Cooke, and Grossman, 1965). The CCK-PZ-elicited release of enzymes was further increased by the effect of bile in the intestinal lumen; this increase was observed both when the common bile duct was patent (Table I, Fig. 1) and when the duct was ligated and the intestine perfused with bile (Table I, Fig. 3).

Secretin also had an effect upon enzyme release, but this was only seen when the common pancreatic and bile duct was patent (Fig. 1), thus this effect was probably indirect and attributable to the effect of secretin on pancreatic and biliary flow.

The increase in alkaline phosphatase observed when the common bile duct was patent (Table I, Fig. 1) may be partially attributable to endogenous biliary and pancreatic alkaline phosphatase. However the large increase observed after CCK-PZ injection when the common bile and pancreatic duct was ligated (Table I, Fig. 2) precludes the possibility that this enzyme had an entirely extraintestinal origin.

The volume increase observed after CCK-PZ injection may be attributed to a number of possible sources, including pancreatic and biliary fluid (Fig. $1)$, as well as to changes in intestinal motility, contraction, and absorption. The increase in enzyme outputs observed in the perfusate after CCK-PZ injection ranged from five to ninefold (Table I); these increases were greatly in excess of the approximately 1.5 -fold increase observed in the total volume of perfusate output. Thus, the changes in total enzyme output after CCK-PZ injection were in fact even greater than the change observed in enzyme concentration. Theoretically the increase in enzyme output could be partly due to a diminution of enzyme degradation due to an acceleration of the passage of fluid through the perfused segment. However the changes observed in volume output which followed CCK-PZ injection were only of 30 to $40 \%$ of the basal rate. Therefore these increases cannot account for the $500-900 \%$ increases in enzyme output.

Although enzyme localization studies (Nordström and Dahlqvist, 1970) make it likely that the source of the released enzymes was the mucosal cells, it is alternatively possible that the functionally uncharacterized glands of Brunner contributed some of this material. It is not possible to decide on the basis of these results whether the bile exerted solely a detergent-like effect upon already released but insoluble enzymes or whether it also directly stimulated the basal release rate of the enzymes (Table I, Fig. 3). Bile perfusion of the intestine has been reported to stimulate pancreatic secretion (Wormsley, 1970; Forell, Stahlheber, and Scholz, 1965).

Previous investigations have led to observations which are consistent with various aspects of the present study. A number of cell types in the intestinal mucosa are morphologically of a secretory type, but the nature of their secretion products and their specific functions have not yet been demonstrated as Trier (1968) has pointed out. Earlier studies (Hadorn et al, 1969, 1971) have shown that enterokinase is present in a soluble form in the intestinal lumen and that bile acids have a solubilizing effect on the brush-border-bound form of the enzyme in vitro. Further studies have shown that bile acids have in addition an activating effect on the system enterokinase-trypsinogen (Steiner, Hadorn, Sumida, and Götze, 1971). Nordström and Dahlqvist (1971) have suggested that pancreatic enzymes may exert similar effects. James, Alpers, Gerber, and Isselbacher (1971) recently demonstrated that the turnover rate in vitro of brush-border disaccharidases is higher than the turnover rate of the epithelial cells themselves. Warnes, Hine, and Kay (1969) have reported increased alkaline phosphatase levels following CCK-PZ injection in the intestine of human subjects, including patients with complete biliary obstruction. Goldman, Kim, Jones, and Sleisenger (1971) have reported glucagon stimulation of enterokinase secretion by Brunner's gland pouches in dogs.

This study has not excluded desquamation as an enzyme-releasing mechanism in the gut. However, if desquamation was responsible for the increased output of enzymes into the lumen, then the process would appear to be both hormonally controlled as well as unexpectedly rapid. It is also possible that the enzyme release in response to CCK-PZ may be due to a more conservative type of secretory process, such as occurs in the physiological response of the pancreas to this hormone. Consistent with this possibility were the rapidity of the intestinal response and the observation that the enterokinase released in the absence of bile upon CCK-PZ injection (Table I, Fig. 2) was not sedimented by centrifugation at $113000 \times g$ for one hour. The CCK-PZ-elicited release of all the enzymes studied was diminished in 
the absence of bile flow (Table I, Fig. 2). The presence of bile alone elicited a lower enzyme output than did the combination of CCK-PZ administration with the concomitant perfusion of bile (Table I, Fig. 3). Under these conditions, the bulk of the luminal enzyme activities was rendered soluble. Further experiments on the participation of bile in this solubilization process is required before the overall mechanism can be understood. At present, the data are consistent with the working hypothesis that the influence of CCK-PZ upon intestinal enzyme levels appears to be two-fold and to consist of a direct stimulation of enzyme release from the cellular sites of origin (in either soluble or insoluble form) and an indirect effect wherein CCK-PZ stimulates bile and pancreatic enzyme flow into the gut where these substances serve to solubilize and/or activate the released enzymes.

We thank Privatdozent Dr D. Kaiser for helpful discussion. This study was supported by grants number 3.483.70 and 3.395.70 of the Schweizerischer Nationalfonds zur Förderung der Wissenschaftlichen Forschung and by a grant from the American-Swiss Foundation for Scientific Exchange to J.W.A.

\section{References}

Crane, R. K. (1968) Absorption of sugars. In Handbook of Physiology, Sect. 6, Alimentary Canal, edited by C. F. Code, Vol. III, pp. 1323-1351. American Physiological Society, Washington, D.C.

Forell, M. M., Stahlheber, H., and Scholz, F. (1965). Galle als Reiz der Enzymsekretion des Pankreas. Dtsch. med. Wschr., 90, 1128-1132.

Goldman, R. B., Kim, Y. S., Jones, R. S., and Sleisenger, M. H. (1971). The effect of glucagon on enterokinase secretion from Brunner's gland pouches in dogs. Proc. Soc. exp. Biol. (N.Y.), 138, 562-565.

Hadorn, B., Steiner, N., Sumida, Ch., and Peters, T. J. (1971).
Intestinal enterokinase, mechanism of its 'secretion' into the lumen of the small intestine. Lancet, 1, 165-166.

Hadorn, B., Tarlow, M. J., Lloyd, J. K., and Wolff, O. H. (1969). Intestinal enterokinase deficiency. Lancet, 2, 812-814.

Hanscom, D. H., and Littman, A. (1963). Dose-response relationships to pancreozymin in normal subjects and patients with chronic pancreatitis. Gastroenterology, 45, 209-214.

Hofstee, B. H. J. (1954). Direct and continuous spectrophotometric assay of phosphomonoesterases. Arch. Biochem., 51, 139-146.

James, W. P. T., Alpers, D. H., Gerber, J. E., and Isselbacher, K. J. (1971). The turnover of disaccharidases and brush border proteins in rat intestine. Biochim. biophys. Acta (Amst.), 230, 194-203.

Lowry, O. H., Rosebrough, N. J., Farr, A. L., and Randall, R. J. (1951). Protein measurement with the Folin phenol reagent. J. biol. Chem., 193, 265-275.

Messer, M., and Dahlqvist, A. (1966). A one-step ultramicro method for the assay of intestinal disaccharidases. Analyt. Biochem. 14, 376-392.

Miller, D., and Crane, R. K. (1961). The digestive function of the epithelium of the small intestine. II. Localization of disaccharide hydrolysis in the isolated brush border portion of intestinal epithelial cells. Biochim. biophys. Acta (Amst.), 52, 293-298.

Nordström, C., and Dahlqvist, A. (1970). The cellular localisation of enterokinase. Biochim. biophys. Acta (Amst.), 198, 621-622.

Paumgartner, G., Horak, W., Probst, P., and Grabner, P. (1971). Effect of phenobarbital on bile flow and bile salt excretion in the rat. Naunyn-Schmiedeberg's Arch. exp. Path. Pharmak., 270, 98-101.

Preshaw, R. M., Adashek, K., Cooke, A. R., and Grossman, M. I. (1965). Failure of urecholine to potentiate the pancreatic response to exogenous stimuli. Proc. Soc. exp. Biol. (N.Y.), 119, 1040-1044.

Semenza, G. (1968). Intestinal oligosaccharidases and disaccharidases In Handbook of Physiology, Sect. 6, Alimentary Canal, edited by C. F. Code, Vol. V, pp. 2543-2566. American Physiological Society, Washington, D.C.

Steiner, N., Hadorn, B., Sumida, Ch., and Götze, H. (1972). Solubilisation and activation of intestinal enterokinase by bile acids. In Proceedings of the European Society for Paediatric Gastroenterology. (Abstr.) Acta paediat. scand., in the press.

Trier, J. S. (1968). Morphology of the epithelium of the small intestine. In Handbook of Physiology, Sect. 6, Alimentary Canal, edited by C. F. Code, Vol. III, pp. 1125-1175. American Physiological Society, Washington, D.C

Warnes, T. W., Hine, P., Kay, G. (1969). Alkaline phosphatase in duodenal juice following secretin and pancreozymin. Gut, 10, 1049.

Wormsley, K. G. (1970). Stimulation of pancreatic secretion by intraduodenal infusion of bile-salts. Lancet, 2, 586-588. 